\title{
The Anthropometry in nutritional and growth assessment of children and adolescents
}

\section{A antropometria na avaliação nutricional e do crescimento de crianças e adolescentes}

\author{
Bruno Sousa \\ School of Sciences and Health Technologies, Universidade Lusófona de Humanidades e Tecnologias, Lisboa, Portugal \\ CBIOS - Research Center for Biosciences and Health Technologies \\ Health Service of Autonomous Region of Madeira \\ Email: bruno.sousa@mail.com
}

\begin{abstract}
For nutritional and growth assessment, anthropometry plays an important role. Specific care for children and adolescents, described within this work, is needed in order to allow a correct evaluation of the situation.

Due to the stage of growth and development of the child and adolescent population, an adequate choice of anthropometric variables, accuracy in measurement, and comparison with appropriate references that reflect the population or individuals to be evaluated are required.

Anthropometry thus plays an important role in the daily clinical practice of the various professionals who evaluate the growth and nutritional status of children and adolescents, but it needs to be correctly used and interpreted.
\end{abstract}

Keywords: anthropometry, nutritional assessment, growth, children, adolescents.

\section{Resumo}

Para a avaliação nutricional e do crescimento a antropometria desempenha um papel importante. Em crianças e adolescentes são necessários cuidados específicos, que são descritos neste trabalho, de forma a permitir um correto diagnóstico da situação.

A população infanto-juvenil, devido à fase de crescimento e desenvolvimento em que se encontra, requer, de acordo com o fim a que se destina, de uma escolha adequada das variáveis antropométricas, do rigor na medição, e da comparação com referências adequadas, que reflitam a população ou indivíduos a avaliar.

A antropometria exerce assim uma função importante na prática clínica diária dos diversos profissionais que avaliam o crescimento e o estado nutricional das crianças e adolescentes, mas necessita de ser corretamente utilizada e interpretada.

Palavras-chave: antropometria, avaliação nutricional, crescimento, crianças, adolescentes 


\section{Introduction}

Anthropometry is the biological science that studies the measurable characteristics of human morphology, and is an essential component for monitoring the health of children or adolescents, as well as epidemiologically determining the nutritional status of a population (1). This is especially important in certain communities where clinical signs of nutritional disorders are rare ${ }^{(2)}$. It is a direct method of nutritional assessment, which is based on the measurement of physical variations and overall body composition at different ages ${ }^{(3)}$. It quantifies the physical dimensions of the body, encompassing the measurement of somatic parameters, which are analysed separately or associated with the diagnosis of the nutritional situation ${ }^{(4,5)}$.

It is widely used in clinical and epidemiology, since it is non-invasive, easy to use, standardised, painless, and low cost, and allows the evaluation data of the individuals to be grouped and analysed, and to provide the evaluation of communities that will establish the nutritional profile of a given group ${ }^{(3,6)}$.

Because weight and height progression is greatly influenced by nutrition, especially in periods of rapid growth, an appropriate choice of anthropometric parameters will give more precise indications about the different types of malnutrition with effects on the development of children and adolescents ${ }^{(2)}$.

Additionally, it has been shown that data and measurements of body composition assessment in adults are not directly applicable in the paediatric population. Therefore, the selection and application of body assessment methods should be specific for this population ${ }^{(7)}$.

\section{Anthropometric Measurements}

Measurements can be obtained directly (e.g. weight, height, body circumferences, skinfolds) or indirectly through indices or formulas based on direct measurements. According to the intended objective (evaluation of growth, body composition, among others), the most adequate anthropometric measurement(s) is used ${ }^{(8)}$. These anthropometric parameters can be used as markers of adiposity (e.g. skinfolds) or fat distribution (e.g. waist circumference) ${ }^{(7)}$.

In infants, weight, length and head circumference, in addition to being the main anthropometric parameters and easy to obtain, are the most sensitive and elective health indicators to evaluate growth and nutritional status ${ }^{(8,9)}$. In children and adolescents there are several anthropo-

\section{Introdução}

A antropometria, é a ciência biológica que estuda as características mensuráveis da morfologia humana, e é um componente essencial para monitorizar a saúde da criança ou adolescente, assim como para determinar epidemiologicamente o estado nutricional de uma população ${ }^{(1)}$, sendo sobretudo importante em certas comunidades onde os sinais clínicos de distúrbios nutricionais são $\operatorname{raros}^{(2)}$.

É um método direto de avaliação nutricional, que baseia-se na medição das variações físicas e da composição corporal global em diferentes idades ${ }^{(3)}$. Quantifica as dimensões físicas corporais, englobando a medição de parâmetros somáticos, que analisados isoladamente ou associados permitem o diagnóstico da situação nutricional ${ }^{(4,5)}$.

É muito usada em clínica e em epidemiologia, visto não ser invasiva, de fácil utilização e padronização, indolor e de baixo custo, permitindo que os dados de avaliação dos indivíduos sejam agrupados, analisados, e forneçam a avaliação de comunidades que originarão o perfil nutricional de um determinado grupo ${ }^{(3,6)}$.

Uma vez que a progressão estaturo-ponderal é grandemente influenciada pela nutrição, em especial nos períodos de crescimento rápido, uma escolha apropriada dos parâmetros antropométricos dará indicações mais precisas sobre os diferentes tipos de malnutrição com efeitos no desenvolvimento da criança e do adolescen$\mathrm{te}^{(2)}$.

Por outro lado, está demonstrado que os dados e as medições da avaliação da composição corporal nos adultos não são diretamente aplicáveis na população pediátrica. Por isso, a seleção e aplicação dos métodos da avaliação corporal devem ser específicos para esta população( ${ }^{(7)}$.

\section{Medidas Antropométricas}

As medidas podem ser obtidas diretamente (ex: peso, estatura, perímetros corporais, pregas cutâneas) ou indiretamente através de índices ou fórmulas baseadas nas medidas diretas. De acordo com o objectivo pretendido (avaliação do crescimento, da composição corporal, entre outros), utiliza-se a(s) medida(s) antropométrica(s) mais adequada $(\mathrm{s})^{(8)}$.

Estes parâmetros antropométricos podem ser usados como marcadores de adiposidade (ex:pregas cutâneas) ou da distribuição da gordura (ex:perímetro da cintura) (7).

Em lactentes, o peso, o comprimento e o perímetro cefálico, para além de serem os parâmetros antropométricos principais e mais fáceis de obter, são os indicadores 
metric parameters to consider, however, only the main ones are described here.

\section{Weight}

Body weight is the basis of human biometry and the most frequently used anthropometric measure ${ }^{(10)}$. It is an excellent indicator of nutritional status and is essential for nutritional assessment, with insufficient weight being one of the best indicators of the prevalence of protein-energy malnutrition. It is also the most important parameter in the definition of situations of overweight and obesity, forms of malnutrition that are more characteristic of industrialized countries and in epidemiological transition ${ }^{(2)}$

Of all the anthropometric parameters, it is the one that offers greater rigor and reproducibility. Therefore, it is the most used measure in the evaluation of the nutritional status, although it does not allow an estimation of the corporal composition. An increase in weight does not necessarily correspond to growth ${ }^{(8)}$.

Weight should be obtained using an electronic scale or an arm scale. The electronic scale tends to be lighter, easier to carry, as well as faster and easier to use. It provides a simple digital reading to interpret, in metric units and, when properly calibrated, is very accurate. Certain digital scales can record weight, which can be an advantage when weighing babies, which tend to resist lying down for the necessary period of time ${ }^{(9)}$.

On horizontal scales with an arm, the "zero" scale must be checked periodically and always after the scale has been moved. Arm balances with wheels, which are transported from one location to another, are not recommended because they must be calibrated each time they are moved ${ }^{(9)}$.

\section{Infants}

Infants should be weighed on an electronic paediatric scale or on an accurate up to $10 \mathrm{~g}$ arm scale. Any shock absorber (towel or cloth diaper) used in the balance tray should be put in place and the scale set to "zero" or its weight be subtracted from the child's weight. They should be weighed without clothing, or the weight of the diaper subtracted from the weight of the infant, and lying in dorsal decubitus position in the middle of the balance ${ }^{(9)}$.

Excessive infant agitation can make it difficult to obtain an exact weight and, in these cases, weighing should be delayed. When too active for weighing on a paediatric scale, infants can be weighed on a platform scale, on an adult's lap, and the weight calculated by the difference from the weight of the adult ${ }^{(9)}$.

\section{Children and adolescents}

de saúde mais sensíveis e de eleição para avaliar o crescimento e o estado nutricional ${ }^{(8,9)}$.

Nas crianças e adolescentes existem vários parâmetros antropométricos a considerar, contudo aqui são descritos apenas os principais.

\section{Peso}

O peso corporal é a base da biometria humana e a medida antropométrica utilizada com mais frequência ${ }^{(10)}$. É um excelente indicador do estado nutricional e é essencial para a avaliação nutricional, sendo a insuficiência ponderal um dos melhores índices da prevalência da malnutrição proteico-energética. É igualmente o parâmetro mais importante na definição de situações de excesso de peso e obesidade, formas de malnutrição mais características dos países industrializados e em transição epidemiológica ${ }^{(2)}$.

De todos os parâmetros antropométricos, é o que oferece maior rigor e reprodutibilidade. Por isso, é a medida mais utilizada na avaliação do estado nutricional, embora não permita uma estimativa da composição corporal. $\mathrm{O}$ aumento ponderal não corresponde necessariamente a crescimento ${ }^{(8)}$

O peso deve ser obtido usando uma balança electrónica ou uma balança de braço. A balança electrónica tende a ser mais leve, fácil de transportar, rápida e fácil de usar. Providencia uma leitura digital simples de interpretar, em unidades métricas e, quando devidamente calibrada, é muito exata. Estas balanças digitais podem gravar o peso, o que pode ser uma vantagem ao pesar bebés, que tendem a resistir enquanto deitados por um determinado período de tempo ${ }^{(9)}$.

Nas balanças horizontais com braço, o "zero" da escala deve ser verificado periodicamente e sempre depois da balança ter sido movimentada. As balanças de braço com rodas, que são transportadas de um local para outro, não são recomendadas porque devem ser calibradas todas as vezes que são mobilizadas ${ }^{(9)}$.

\section{Lactentes}

Os lactentes devem ser pesados numa balança pediátrica electrónica ou numa balança de braço exata até às 10g. Qualquer amortecedor (toalha ou fralda de pano) usado na bandeja da balança, deve ser colocado no lugar e a escala ajustada a "zero" ou o seu peso ser subtraído ao peso da criança. Devem ser pesados sem roupa ou subtraído o peso da fralda ao peso do lactente, e estar deitados em decúbito dorsal no meio da balança ${ }^{(9)}$. A excessiva agitação infantil pode tornar difícil a obtenção de um peso exato e, nestes casos, a pesagem deve ser adiada. Quando muito ativos para se pesarem numa balança pediátrica, os lactentes podem ser pesa- 
Children and adolescents, who can stand without assistance, can be weighed on an electronic platform scale or with an accuracy of at least $100 \mathrm{~g}$. They should be standing and still, in the middle of the platform, without touching other objects, and with the body weight distributed evenly on both feet. Ideally, they should be weighed after they have undressed, wearing an exam gown of known weight or light underwear ${ }^{(9)}$.

\section{Length and height}

Length (for infants) or height is an indicator that quantifies linear growth related to skeletal growth ${ }^{(8)}$. It is simple to measure and a parameter that can be a significant indicator of growth and development ${ }^{(11)}$.

Regarding height, growth is delayed when protein intake is inadequate or if the energy deficit persists over a long period of time and it is therefore particularly an indicator of chronic malnutrition ${ }^{(4)}$.

\section{Length}

Length is obtained with the child lying in dorsal decubitus position and is usually directed to children less than 24 months of age or to children between 24 and 36 months who cannot be in an upright position without assistance. It should be noted that growth charts used for children from birth to 36 months of age are based on length, while for individuals aged 2 to 20 years they are based on height ${ }^{(9)}$.

Measuring the length requires special equipment, with a stationary head plate and a movable planting plate, perpendicular to the back plate. The scale of the measuring device should start at the tip of the head plate and allow the child's length to be read from the planting plate ${ }^{(9)}$.

Two people are required to evaluate a child's length. With the child in dorsal decubitus position, a person holds the child's head against the back and head plates, and with the Frankfort plane perpendicular to the back plate. This same person also maintains the centreline of the child's body aligned with the centreline of the back plate, the shoulder blades and buttocks touching the back plate, and the shoulders and hips at right angles to the centreline along the body. The other person holds the child's legs straight and against the back plate, slides the planting plate against the feet (without shoes and socks) with the toes pointing up, and reads dos numa balança de plataforma, ao colo de um adulto e o peso calculado pela diferença do peso do adulto ${ }^{(9)}$.

\section{Crianças e adolescentes}

As crianças e adolescentes que consigam estar de pé, sem assistência, podem ser pesadas numa balança de plataforma electrónica ou numa balança de braço exata até às $100 \mathrm{~g}$. Devem estar de pé e imóveis, a meio da plataforma, sem tocar em nada e com o peso corporal distribuído igualmente por ambos os pés. Idealmente, deviam ser pesados depois de se despirem e vestirem uma bata de exame com peso conhecido ou em roupa interior leve ${ }^{(9)}$.

\section{Comprimento e estatura}

É um indicador que quantifica o crescimento linear relacionado com o crescimento do esqueleto ${ }^{(8)}$. É simples, e constitui um parâmetro que pode ser um indicador significativo de crescimento e desenvolvimento ${ }^{(11)}$.

$\mathrm{Na}$ estatura, o crescimento é retardado quando a ingestão proteica é inadequada ou se o défice energético persiste por um longo período no tempo, sendo portanto particularmente um indicador de desnutrição crónica ${ }^{(4)}$.

\section{Comprimento}

É obtido com a criança deitada em decúbito dorsal e geralmente é orientado para crianças com menos de 24 meses de idade ou para crianças entre os 24 e os 36 meses que não consigam estar numa posição erecta, sem assistência. Há que ter em consideração que, as tabelas de crescimento usadas para crianças desde o nascimento aos 36 meses de idade são baseadas no comprimento, enquanto que, para os indivíduos com idades entre os 2 e os 20 anos são baseadas na estatura ${ }^{(9)}$.

A medição do comprimento requer um equipamento especial, com uma placa cefálica estacionária e uma placa plantar móvel, perpendiculares à placa traseira. A escala do aparelho de medição deve iniciar-se na ponta da placa cefálica e deve permitir que o comprimento da criança seja lido a partir da placa plantar ${ }^{(9)}$.

São necessárias duas pessoas para avaliar o comprimento. Com a criança em decúbito dorsal, uma pessoa segura a cabeça da criança contra as placas traseira e cefálica, e com o plano de Frankfort perpendicular à placa traseira. Esta mesma pessoa mantém também a linha central do corpo da criança alinhada com a linha central da placa traseira, as omoplatas e nádegas tocando na placa traseira, e os ombros e as ancas nos ângulos direitos à linha central ao longo do corpo. A outra pessoa mantém as pernas da criança direitas e contra a placa traseira, desliza a placa plantar contra os pés (sem sa- 
the measurement. The planting plate should be firmly pressed so as to compress the soft tissues of the soles of the feet, but without shortening the length of the spine. The length should be recorded to the nearest $0.1 \mathrm{~cm}^{(9)}$.

\section{Height}

Height can be evaluated in children over 2 years of age, provided that they are able to maintain a vertical position without assistance ${ }^{(9)}$.

For this measurement a stadiometer is used, and the child must be standing without shoes, with the heels together, arms at the side of the body, straight legs, relaxed shoulders and the head in the Frankfort horizontal plane. The heels, buttocks, shoulder blades, and back of the head should, if possible, be against the vertical surface of the stadiometer. For measurement, an erect posture should be maintained while the head plaque is placed against the highest point of the head with sufficient pressure to compress the hair. The measurement should be read up to $0.1 \mathrm{~cm}$ and with the eyes at the level of the head plaque. Hair ornamentation may have to be removed if it interferes with the measurement ${ }^{(9)}$.

\section{Circumferences}

In assessing the body circumferences, namely those of the limbs, these include the skin, subcutaneous tissue, muscle, bone, blood vessels and nerves. The trunk, such as the waist, also includes visceral adipose tissue and viscera ${ }^{(8)}$. These anthropometric measurements are based on the concept that the circumferences reflect fat mass and fat-free mass, and are useful for determining fat distribution ${ }^{(7)}$.

For its measurement a soft and inextensible measuring tape is required ${ }^{(9)}$. The evaluation of limb circumferences can be performed in the right or left body side, however it is normal practice to measure the non-dominant side

\section{Head circumference}

The measurement of head circumference is essential for early identification of central nervous system developmental abnormalities, but it is not an essential parameter to characterise an individual's nutritional status ${ }^{(2,4)}$. It is the last parameter to be affected by chronic proteinenergy malnutrition ${ }^{(10)}$, but after three years of age, the relationship between nutrition and head circumference is very small ${ }^{(11)}$.

For its measurement, the measuring tape is applied around the frontal region, just above the orbital arcade patos e sem meias) com os dedos apontando para cima, e lê a medição. A placa plantar deve ser pressionada firmemente de forma a comprimir os tecidos moles das plantas dos pés, mas sem diminuir o comprimento da coluna vertebral. O comprimento deve ser registado até ao $0,1 \mathrm{~cm}$ mais próximo $^{(9)}$.

\section{Estatura}

Pode ser avaliada em crianças com idades superiores aos 2 anos, desde que colaborantes e capazes de manter uma posição vertical sem assistência ${ }^{(9)}$.

Para esta medição utiliza-se um estadiómetro, e a criança deve estar de pé, sem sapatos, com os calcanhares juntos, braços ao lado do corpo, pernas direitas, ombros relaxados e a cabeça no plano horizontal de Frankfort. Os calcanhares, as nádegas, as omoplatas e a parte posterior da cabeça devem, se possível, estar contra a superfície vertical do estadiómetro. Para a medição, deve manter uma postura erecta, enquanto a placa cefálica é colocada contra o ponto mais alto da cabeça com pressão suficiente para comprimir o cabelo. A medida deve ser lida até $0,1 \mathrm{~cm}$ e com os olhos ao nível da placa cefálica. A ornamentação do cabelo pode ter que ser removida se interferir com a medição ${ }^{(9)}$.

\section{Perímetros}

Ao avaliar os perímetros corporais, nomeadamente os dos membros, estes incluem a pele, tecido subcutâneo, músculo, osso, vasos sanguíneos e nervos. Os do tronco, como o da cintura, incluem ainda o tecido adiposo visceral e as vísceras ${ }^{(8)}$. Estas medidas antropométricas são baseadas no conceito que os perímetros refletem a massa gorda e a massa isenta de gordura, e são úteis para determinar a distribuição de $\operatorname{gordura}^{(7)}$.

Para a sua medição é necessária uma fita métrica mole e inextensível ${ }^{(9)}$. A avaliação dos perímetros dos membros pode ser realizada no hemicorpo do lado direito ou esquerdo, no entanto existe a prática de realizar no lado não dominante.

\section{Perímetro cefálico}

A medição do perímetro cefálico é essencial para identificar precocemente as anormalidades do desenvolvimento do sistema nervoso central, mas, não é um parâmetro essencial para caracterizar o estado nutricional de um indivíduo ${ }^{(2,4)}$.

É o último a ser afectado pela malnutrição proteico-energética crónica ${ }^{(10)}$, mas depois dos 3 anos de idade, a relação entre nutrição e perímetro cefálico é muito pequena $^{(11)}$.

Para a sua medição, aplica-se a fita métrica mole e inex- 
and staying at the same level on each side of the skull, passing the tape over the external occipital protuberance, and establishing sufficient pressure to compress the hair. The measurement should be made to the nearest $0.1 \mathrm{~cm}^{(9)}$.

\section{Mid-upper arm circumference}

The evaluation of mid-upper arm circumference (MUAC) is a practical, simple and useful means of assessing protein-energy malnutrition, ${ }^{(2)}$ as it reflects both fat and muscle depletion. Conversely, in obesity, MUAC is higher than normal as a result of increased subcutaneous fat ${ }^{(12)}$.

MUAC and especially the upper arm muscular circumference (UAMC) and muscle mass reflect the main protein reserves of the individual ${ }^{(4,5)}$. In this way, it represents the combination of muscle and adipose masses of the arm, as it is considered a somatic reserve of protein and fat $^{(8)}$.

MUAC is measured in the middle distance between the lateral projection of the acromion and the lower margin of the olecranon. To facilitate its determination, the elbow should be bent at $90^{\circ}$. The measurement is performed with the arm relaxed along the body and the measuring tape positioned at the indicated location, firmly but without exerting pressure. The value should be determined to the nearest $0.1 \mathrm{~cm}^{(9.12)}$.

\section{Upper arm muscular circumference}

Upper arm muscular circumference (UAMC) is a marker of nutritional status and protein reserves ${ }^{(5)}$. It is calculated from the values of triceps skinfold thickness (TST) and MUAC, using the formula: UAMC = MUAC - $(\pi \times \text { TST })^{(12)}$.

\section{Waist circumference}

Waist circumference is an easily measured indicator of central fat ${ }^{(13)}$ and cardiovascular risk ${ }^{(14)}$. It is a specific, high sensitivity measurement and should be evaluated to identify overweight and obese children at risk of developing metabolic complications ${ }^{(15)}$.

For the evaluation of this parameter, the child or adolescent should be comfortable, with their weight evenly distributed over both feet and with these separated $25-$ $30 \mathrm{~cm}$. It is performed at the midpoint between the last rib and the iliac crest, in a horizontal plane and at the end of a normal exhalation. The measurement should be recorded up to $0.1 \mathrm{~cm}^{(16,17)}$.

\section{Thigh circumference}

Thigh circumference should be measured at a point equidistant from the inguinal line to the upper edge of tensível à volta do frontal, logo por cima da arcada orbitária e mantém-se ao mesmo nível de cada lado do crânio, fazendo-a passar sobre a protuberância occipital externa, estabelecendo uma pressão suficiente para comprimir o cabelo. A medição deve ser feita com a aproximação de $0,1 \mathrm{~cm}^{(9)}$.

\section{Perímetro do braço}

A avaliação do perímetro do braço (PB) é um meio prático, simples e útil na avaliação da malnutrição proteico-energética ${ }^{(2)}$. Reflete tanto a depleção de gordura como muscular. Na obesidade, pelo contrário, o PB é superior ao normal, como resultado do aumento de gordura subcutânea ${ }^{(12)}$.

$\mathrm{O}$ PB e especialmente o perímetro muscular do braço (PMB) e a massa muscular refletem as principais reservas proteicas do organismo ${ }^{(4,5)}$. Representa desta forma, a combinação das massas muscular e adiposa do braço, sendo considerado um marcador de reserva somática proteica e gorda ${ }^{(8)}$.

É medido na meia distância entre a projeção lateral do acrómio e a margem inferior do olecrâneo. Para facilitar a sua determinação o cotovelo deve ser flectido a $90^{\circ}$. A medição é realizada com o braço relaxado ao longo do corpo e posicionada a fita métrica no local estabelecido, firmemente sem exercer pressão. $\mathrm{O}$ valor deve ser determinado com uma aproximação até $0,1 \mathrm{~cm}^{(9,12)}$.

\section{Perímetro muscular do braço}

Constitui um marcador do estado nutricional e das reservas proteicas ${ }^{(5)}$. É calculado a partir dos valores da prega cutânea tricipital (PCT) e do $\mathrm{PB}$, através da fórmula: $\mathrm{PMB}=\mathrm{PB}-(\pi \times \mathrm{PCT})^{(12)}$.

\section{Perímetro da cintura}

É um indicador da gordura central, de fácil medição ${ }^{(13)} \mathrm{e}$ factor de risco cardiovascular ${ }^{(14)}$. Trata-se de uma medida específica de grande sensibilidade da gordura corporal central e deve ser avaliada para identificar crianças com excesso de peso e obesas, com risco de desenvolver complicações metabólicas ${ }^{(15)}$.

Para a avaliação deste parâmetro, a criança ou adolescente deve estar confortável, com o seu peso uniformemente distribuído por ambos os pés e com estes separados $25-30 \mathrm{~cm}$. É realizada no ponto médio entre a última costela e a crista ilíaca, num plano horizontal e no final de uma normal expiração. A medição deve ser registada até $0,1 \mathrm{~cm}^{(16,17)}$.

\section{Perímetro da coxa}

Deve ser medido num ponto equidistante entre a linha inguinal e o bordo superior da rótula, perpendicular- 
the patella, perpendicular to the longitudinal axis of the thigh. To better locate the inguinal line, the child or adolescent may flex the hip. The subject stands erect with feet slightly apart and weight evenly distributed over both feet, with the measurement performed at the site indicated to the nearest $0.1 \mathrm{~cm}^{(9.18)}$.

\section{Leg circumference}

Leg circumference should be performed at the contralateral region and may indicate the total fat reserve (8)

For its measurement, the individual should position himself/herself in an elevated position with respect to the evaluator, for example, on top of a box or bench, in order to facilitate reading by the evaluator. The weight should be distributed evenly across both feet and the measurement performed on the lateral side of the leg. The measuring tape is placed around this region, locating the maximum circumference by handling the tape in a series of up and down measurements with the help of the middle fingers. The measurement should be performed to the nearest $0.1 \mathrm{~cm}^{(9.18)}$.

\section{Skinfolds}

The measurement of skinfolds is a simple and immediate process of determining subcutaneous fat, revealing body energy reserves ${ }^{(5)}$. In this way, we can say they provide a theoretical estimation of the deposition of subcutaneous fat and, indirectly, the total body fat ${ }^{\left({ }^{8}\right)}$. Skinfolds in children and adolescents can be used to estimate body density, fat-free mass, fat mass and body fat percentage through the conjugation of appropriate and validated equations for the paediatric population ${ }^{(7)}$. Since subcutaneous fat deposits are not uniform throughout the body, it is necessary to choose the most suitable regions ${ }^{(5)}$. The tricipital, bicipital, subscapular and suprailiac regions are usually recommended for children and adolescents ${ }^{(4,5)}$.

For these measurements, a lipocalibrator or compass of thickness should be used ${ }^{(8)}$.

Skinfold measurement is the most usual method of indirect calculation of the percentage of body fat at the clinical level. Although there are more accurate methods, the measurement of skinfolds has many advantages: the necessary equipment is low cost and requires little space, the measurements are easy and quick to perform, and, when correctly evaluated, the measurements provides estimates of body composition that correlate well with those obtained by hydrostatic weighing ${ }^{(9)}$.

Assumptions for the measurement of skinfolds: mente ao eixo longitudinal da coxa. Para melhor localizar a linha inguinal, a criança ou adolescente pode flectir a anca. O sujeito posiciona-se erecto, com os pés ligeiramente afastados e o peso uniformemente distribuído sobre os dois pés e realizada a medição no local determinado com uma aproximação até $0,1 \mathrm{~cm}^{(9,18)}$.

\section{Perímetro da perna}

Deve ser realizado ao nível da região gemelar e poderá indicar a reserva gorda total ${ }^{(8)}$.

Para a sua medição, o indivíduo deve posicionar-se numa posição elevada relativamente ao avaliador, por exemplo, em cima de uma caixa ou banco, de forma a facilitar a leitura por parte do avaliador. O peso deve ficar distribuído uniformemente por ambos os pés e a medição realizada na face lateral da perna. Coloca-se a fita à volta desta região até encontrar a circunferência máxima com o auxílio dos dedos médios, através do manuseamento da fita numa série de medições para cima e para baixo. A medição deve ser realizada com uma aproximação até $0,1 \mathrm{~cm}^{(9,18)}$.

\section{Pregas cutâneas}

A medição das pregas cutâneas constitui um processo simples e imediato de determinar a gordura subcutânea, revelando as reservas energéticas corporais ${ }^{(5)}$. Desta forma, podemos dizer que, teoricamente estimam o depósito de gordura subcutânea e indiretamente a gordura corporal total ${ }^{(8)}$.

As pregas cutâneas em crianças e adolescentes podem ser usadas para estimar a densidade corporal, a massa isenta de gordura, massa gorda e a percentagem de gordura corporal através da conjugação de equações apropriadas e validadas para a população pediátrica ${ }^{(7)}$.

Como os depósitos de gordura subcutânea não são uniformes em todo o corpo, é necessário escolher as regiões mais adequadas ${ }^{(5)}$. As habitualmente recomendadas para as crianças e adolescentes são a tricipital, a bicipital, a subescapular e a suprailíaca ${ }^{(4,5)}$.

Para estas medições deve ser utilizado um lipocalibrador ou compasso de espessura ${ }^{(8)}$.

É o método mais usual de cálculo indireto da percentagem de gordura corporal a nível clínico. Apesar de existirem métodos mais exatos, a medição das pregas tem as vantagens do equipamento necessário ser de baixo custo e requerer pouco espaço; as medições serem fáceis e rápidas de realizar e, quando corretamente avaliadas, fornecem estimativas de composição corporal que se correlacionam bem com as obtidas por pesagem hidrostática ${ }^{(9)}$. 
The thickness of the subcutaneous adipose tissue varies greatly between the different sites of folds in an individual and the same location of the fold between individuals. Consequently, total subcutaneous adipose tissue is best evaluated by measuring multiple sites of cutaneous folds; a minimum of three locations is recommended. Proper selection of sites is crucial, as there is a high correlation between the values of the folds at certain sites and the total subcutaneous adipose tissue. The sites of the lower limbs may be included in the predictive formulas of body composition ${ }^{(9)}$.

Considerations of the technique of measurement of the skinfolds:

Most US researchers measure the folds on the right side of the body, while Europeans typically measure on the left side, however, the measurement side is not relevant. As a general rule, those with little experience in the measurement of skinfolds should mark the place to be measured after it has been carefully identified. A flexible, non-stretchable measuring tape can be used to locate midpoints in the body; the fold should be grasped by the thumb and index finger of the left hand, about $1 \mathrm{~cm}$ from the site to be evaluated, and should be lifted away from the body, making sure that it does not cling to muscle. This is usually easy on more lean individuals, but can be difficult and also uncomfortable on those who are obese. The evaluator should hold the lipocalibrator with the right hand, perpendicular to the centreline of the fold and with the scale facing up for easy reading. The tips of the lipocalibrator should be placed about $1 \mathrm{~cm}$ from the fingers that hold the crease so that the pressure of the fingers does not affect the measured value, and should not be placed too deep nor too close to the end of the crease. The evaluator should try to visualize the true skinfold and place the tips of the lipocalibrator at that location; the measurement is read for about four seconds after the pressure of the evaluator's hand has been relieved from the arm of the lipocalibrator lever. If the lipocalibrator tips exert force for more than four seconds, the reading gradually becomes a smaller value as the fluids are forced and the tissues compressed. The readings should be recorded up to $1 \mathrm{~mm}$ or $2 \mathrm{~mm}$, depending on the equipment used. The evaluator must maintain pressure on the crease with the thumb and index finger throughout the measurement. In the measurement of the obese, it may be impossible to raise a fold with parallel sides, particularly at the abdominal level. In this situation, the evaluator can use both hands to get the fold while a colleague measures the fold. If this is too large for the lipocalibrator, another technique will have to be used. Additionally, measurements should not be made imme-
Pressupostos da medição das pregas cutâneas:

A espessura do tecido adiposo subcutâneo varia grandemente entre os diferentes locais de pregas num indivíduo e para o mesmo local da prega entre indivíduos. Consequentemente, o total de tecido adiposo subcutâneo é melhor avaliado, medindo múltiplos locais de pregas cutâneas; é recomendado um mínimo de três locais; a seleção apropriada dos locais é crucial; existe uma correlação elevada entre os valores das pregas em certos locais e o tecido adiposo subcutâneo total; os locais dos membros inferiores podem ser incluídos nas fórmulas preditivas da composição corporal ${ }^{(9)}$.

Considerações da técnica de medição das pregas cutâneas:

A maioria dos investigadores norte-americanos mede as pregas do lado direito do corpo, enquanto os europeus fazem-no tipicamente do lado esquerdo. No entanto, é pouco relevante o lado onde se fazem as medições; como regra geral, aqueles com pouca experiência na medição de pregas devem marcar o local a ser medido, depois de este ter sido cuidadosamente identificado. Uma fita métrica flexível e não extensível pode ser usada para localizar os pontos médios no corpo; a prega deve ser agarrada pelo dedo polegar e o indicador da mão esquerda, a cerca de $1 \mathrm{~cm}$ do local a ser avaliado, e deve ser elevada distanciando-se do corpo, certificando-se que não se agarra em músculo. Isto é habitualmente fácil em pessoas magras, mas pode ser difícil e também desconfortável em pessoas obesas; deve-se segurar no lipocalibrador com a mão direita, perpendicular à linha central da prega e com a escala voltada para cima, para fácil leitura. As pontas do lipocalibrador devem ser colocadas no local, a cerca de $1 \mathrm{~cm}$ dos dedos que seguram a prega, para que a pressão dos dedos não afetem o valor medido; o lipocalibrador não deve ser colocado demasiado profundo nem demasiado perto da extremidade da prega. $\mathrm{O}$ avaliador deve tentar visualizar onde está a verdadeira dobra de pele e colocar as pontas do lipocalibrador nesse local; a medição é lida até cerca de 4 segundos, depois da pressão feita pela mão do avaliador ter sido aliviada do braço da alavanca do lipocalibrador. Se as pontas do lipocalibrador exercerem força por mais de 4 segundos, a leitura gradualmente torna-se mais pequena assim que os fluidos são forçados e os tecidos comprimidos. As leituras devem ser registadas até ao $1 \mathrm{~mm}$ ou $2 \mathrm{~mm}$, dependendo do equipamento utilizado; o avaliador deve manter a pressão com o polegar e o dedo indicador durante toda a medição; na medição de obesos, pode ser impossível elevar uma prega com lados paralelos, particularmente a nível abdominal. Nesta situação, o avaliador pode usar ambas as mãos para obter a prega, enquanto um 
diately after exercise or when the child or adolescent is overheated, as the movement of body fluids to the skin may increase the normal size of the skinfold ${ }^{(9)}$.

Given these assumptions and the considerations of cutaneous folds, it is suggested that these measurements, as well as the respective circumferences, be performed in the non-dominant side of the subject and that each operation be repeated twice and the arithmetic mean calculated.

\section{Triceps skinfold thickness}

Because of its accessibility, the triceps are the most common place for skinfold measurement. These are located in the posterior aspect of the arm, on the triceps muscle, in the middle distance between the lateral projection of the acromion and the inferior margin of the olecranon. This midpoint should be marked along the lateral side of the arm, with the elbow flexed at $90^{\circ}$. To determine the midline, the subject's arm should be relaxed beside the body with the palm of the hand turned anteriorly. The fold site should be marked along the posterior midline of the arm, at the same level as the premarked midpoint. The evaluator should stand behind the subject, grasping the fold with the thumb and index finger of the left hand, about $1 \mathrm{~cm}$ from the crease site. The lipocalibrator lies perpendicularly along the centreline, and thus the measurement value can be easily read ${ }^{(9)}$.

The TST determination has the added advantage that, in conjunction with MUAC, it is possible to calculate the UAMC and upper arm muscular area (UAMA) and, in turn, the upper arm fat area (UAFA), knowing the upper arm total area (UATA) ${ }^{(4,5,19)}$. This is important for a better characterisation of the body composition.

\section{Bicipital skinfold thickness}

For this evaluation, the same procedures described for TST are followed, however, the measurement is performed in the anterior part of the arm, over the biceps muscle, with the evaluator positioned in front of the subject ${ }^{(9,16)}$.

\section{Subscapular skinfold thickness}

The subscapular region lies $1 \mathrm{~cm}$ below the lower scapular angle. The centreline of the fold is $45^{\circ}$ directed downward and to the outer side of the body. The site can be located by sensing the lower scapular angle or by asking the child or adolescent to place their arm behind their back. It is measured with the subject standing, arms relaxed at the side of the body. The fold is grasped $1 \mathrm{~cm}$ above the measurement site and read from the lipocalibrator ${ }^{(9)}$. colega mede a prega. Se esta for demasiado larga para o lipocalibrador, outra técnica terá que ser utilizada; as medições não devem ser feitas imediatamente após o exercício físico ou quando a criança ou adolescente está sobreaquecida, pois a deslocação dos fluidos corporais para a pele poderá aumentar o tamanho normal da prega cutânea $^{(9)}$.

Tendo em conta estes pressupostos e as considerações das pregas cutâneas, sugere-se que estas medições, assim como os respetivos perímetros, sejam realizados no hemicorpo do lado não dominante do sujeito e que cada operação seja repetida duas vezes e calculada a média aritmética.

\section{Prega cutânea tricipital}

Devido à sua acessibilidade, é o local mais comum para a medição da prega cutânea. Esta situa-se na face posterior do braço, sobre o músculo tríceps, na meia distância entre a projeção lateral do acrómio e a margem inferior do olecrâneo. Este ponto médio deve ser marcado ao longo da face lateral do braço, com o cotovelo fletido a $90^{\circ}$. Para determinar a linha média, o braço do sujeito deve estar relaxado ao lado do corpo, com a palma da mão virada anteriormente. $\mathrm{O}$ local da prega deve ser marcado ao longo da linha média posterior do braço, ao mesmo nível do ponto médio previamente marcado. O avaliador deve colocar-se de pé, atrás do sujeito, agarrar a prega com o dedo polegar e o indicador da mão esquerda, a cerca de $1 \mathrm{~cm}$ do local da prega. O lipocalibrador fica perpendicularmente ao longo da linha central, e assim o valor da medição pode ser facilmente lido $^{(9)}$.

A determinação da PCT tem a vantagem acrescida de, em conjugação com o $\mathrm{PB}$, permitir calcular o PMB e a área muscular do braço (AMB) e, por sua vez, a área gorda do braço (AGB), conhecendo a área total do braço (ATB $)^{(4,5,19)}$, importantes para uma melhor caracterização da composição corporal.

\section{Prega cutânea bicipital}

Para esta avaliação, segue-se os mesmos procedimentos descritos para a PCT, no entanto, a medição é realizada na parte anterior do braço, sobre o músculo bíceps, com o avaliador colocado em frente ao sujeito ${ }^{(9,16)}$.

\section{Prega cutânea subescapular}

Situa-se $1 \mathrm{~cm}$ abaixo do ângulo escapular inferior. A linha central da prega é $45^{\circ}$ dirigida para baixo e para o lado externo do corpo. O local pode ser localizado ao sentir o ângulo escapular inferior ou pedindo à criança ou adolescente para colocar o seu braço atrás das costas. É medido com o sujeito em pé, com os braços rela- 


\section{Suprailiac skinfold thickness}

This fold is measured just above the iliac crest, in the mid axillary line. The central line follows the natural segmentation lines of the skin and runs diagonally downward toward the median plane of the body. The subject should be in an upright position with arms at the side of the body, although the arm on the side of the measurement may be moved away from the body and slightly flexed to facilitate access to the site. The evaluator should grasp the fold about $1 \mathrm{~cm}$ posterior to the medial axillary line and measure with the lipocalibrator $^{(9,18)}$.

\section{Abdominal skinfold thickness}

For evaluation of the abdominal skinfold, the child or adolescent should be in an erect position, with body weight distributed equally by both feet, the abdominal muscle relaxed and breathing normally. It is evaluated horizontally, $3 \mathrm{~cm}$ for the outer side and $1 \mathrm{~cm}$ below the midpoint of the navel ${ }^{(9)}$.

\section{Thigh skinfold thickness}

The measurement of thigh skinfold thickness is made along the midline of the anterior aspect of the thigh at the midpoint between the inguinal line and the upper edge of the kneecap. To better locate the inguinal line, the child or adolescent may flex the hip. The subject shifts his weight to the foot contrary to that of the measurement and relaxes the leg, with the fold being evaluated in the direction of the longitudinal axis, flexing slightly the knee, with the foot well resting on the floor ${ }^{(9)}$.

\section{Leg skinfold thickness}

Leg skinfold thickness is obtained with the subject sitting and with the bent leg $90^{\circ}$ at the level of the knee, with the foot well resting on the ground. The measurement can also be made with the subject standing, with the foot resting on a platform, so that the knee and the hip are bent about $90^{\circ}$. The maximum circumference point of the lower leg is marked and the measurement performed on the lateral side of the leg. A vertical fold is grasped about $1 \mathrm{~cm}$ proximal to the marked location and the measurement is performed with the lipocalibrator ${ }^{(9)}$.

Measurement of fold in a single location

Although measurement of the fold in a single location cannot be used to estimate the percentage of body fat, it is nevertheless useful for comparisons with reference data, where available. The triceps are usually used ${ }^{(9)}$.

Using the measurement of the fold in a single location xados ao lado do corpo. A prega é agarrada $1 \mathrm{~cm}$ acima do local da medição e efectuada a sua leitura ${ }^{(9)}$.

\section{Prega cutânea suprailiaca}

Esta prega é medida logo acima da crista ilíaca, na linha axilar média. A linha central segue as linhas de segmentação naturais da pele e dirige-se diagonalmente para baixo em direção ao plano mediano do corpo. O sujeito deve estar na posição erecta, com os braços ao lado do corpo, apesar do braço do lado da medição poder estar em abdução e ligeiramente flectido, para facilitar o acesso ao local. $\mathrm{O}$ avaliador deve agarrar a prega a cerca de $1 \mathrm{~cm}$ posterior à linha axilar média e medi-la ${ }^{(9,18)}$.

\section{Prega cutânea abdominal}

Para a avaliação desta prega, a criança ou adolescente deve estar na posição erecta, com o peso corporal distribuído igualmente por ambos os pés, os músculos abdominais relaxados e respirando normalmente. É avaliada horizontalmente, $3 \mathrm{~cm}$ para o lado exterior e a $1 \mathrm{~cm}$ abaixo do ponto médio do umbigo ${ }^{(9)}$.

\section{Prega cutânea da coxa}

Localiza-se ao longo da linha média da face anterior da coxa, no ponto médio entre a linha inguinal e o bordo superior da rótula. Para melhor localizar a linha inguinal, a criança ou adolescente pode flectir a anca. O sujeito muda o seu peso para o pé contrário ao da medição e relaxa a perna, sendo a prega avaliada na direção do eixo longitudinal, ao flectir ligeiramente o joelho, com o pé bem assente no chão ${ }^{(9)}$.

\section{Prega cutânea da perna}

Obtém-se com o sujeito sentado e com a perna flectida $90^{\circ}$ ao nível do joelho, com o pé bem assente no chão. A medição também pode ser feita com sujeito de pé, com o pé a descansar sobre uma plataforma, para que o joelho e a anca fiquem flectidos cerca de $90^{\circ}$. O ponto de circunferência máxima da barriga da perna é marcado e a medição realizada na face lateral da perna. Uma prega vertical é agarrada cerca de $1 \mathrm{~cm}$ próximo do local marcado e efectuada a medição ${ }^{(9)}$.

\section{Medição de prega num único local}

Apesar da medição da prega num único local não poder ser usada para estimar a percentagem de gordura corporal é, no entanto, útil para realizar comparações com dados de referência, quando disponíveis. O triceps é o local habitualmente utilizado ${ }^{(9)}$.

Usar a medição da prega num único local tem as suas limitações: não é consensual qual é o melhor local; não existem equações para calcular a gordura corporal 
has its limitations: there is no agreement on which is the best place; there are no equations for calculating body fat using only tricipital fold measurement; multiple anthropometric measurements are required to achieve a reasonably accurate calculation of body composition due to variations in the distribution of subcutaneous adipose tissue.

Measurement of folds in two locations

The most frequently used approach to assess the body composition of individuals aged 6 to 20 years utilises the sum of triceps and subscapular skinfolds. These folds have the advantage of correlating with other measures of body fat, and are sites that are evaluated with greater objectivity and confidence than most others ${ }^{(9)}$.

However, other forms of evaluation were developed using the sum of triceps and leg folds measurements. This sum proved to be a reliable and reasonably valid indicator of body composition ${ }^{(9)}$.

Measurement of folds at multiple locations

Predicting body density and then body fat percentage from the folds measurement requires regression equations. These formulas were developed by comparing several folds with other anthropometric techniques for assessing body density (usually by hydrostatic weighing), to conclude the best anthropometric measurements that predict body density ${ }^{(9)}$.

The regression equations that have been developed can be classified as specific equations for certain populations or generalized equations. Specifics have been derived from data from groups of individuals who share certain characteristics, such as age and gender ${ }^{(9)}$.

\section{Arm cross-sectional areas}

Many authors prefer arm cross-sectional areas as a method of nutritional assessment, arguing that they better estimate the relative contribution of fat and muscle to UATA compared to isolated MUAC and TST values (8)

Using reference methods - computerized axial tomography and magnetic resonance imaging - the respective cross-sectional areas estimated by anthropometry were validated for both children and adults when using the arm images ${ }^{(8)}$.

\section{Upper arm total area}

Upper arm total area is calculated from the expression: $\mathrm{UATA}=\mathrm{MUAC}^{2} /(4 \mathrm{x} \pi)^{(19)}$ usando apenas a medição da prega tricipital; medidas antropométricas múltiplas são necessárias para atingir um cálculo da composição corporal razoavelmente exato, devido às variações da distribuição do tecido adiposo subcutâneo.

\section{Medição de pregas em dois locais}

A aproximação mais frequentemente usada para avaliar a composição corporal de indivíduos dos 6 aos 20 anos utiliza a soma da tricipital e da subescapular. Estas pregas têm a vantagem de se correlacionarem com outras medidas de gordura corporal, e serem locais avaliados com maior objectividade e confiança que a maioria dos outros $^{(9)}$.

Contudo foram desenvolvidas outras formas usando a soma das medições das pregas tricipital e da perna. Esta soma provou ser um indicador confiável e razoavelmente válido da composição corporal ${ }^{(9)}$.

\section{Medição de pregas em múltiplos locais}

Prever a densidade corporal e depois a percentagem de gordura corporal a partir da medição das pregas, requer equações de regressão. Estas fórmulas foram desenvolvidas por comparação de várias pregas com outras técnicas antropométricas de avaliação da densidade corporal (habitualmente pela pesagem hidrostática), para concluir quais as melhores medidas antropométricas que predizem a densidade $\operatorname{corporal}^{(9)}$.

As equações de regressão que foram desenvolvidas, podem ser classificadas como equações específicas para certas populações ou equações generalizadas. As específicas derivam de dados de grupos de indivíduos que partilham certas características, como a idade e o $\operatorname{sexo}^{(9)}$.

\section{Áreas da secção transversal do braço}

Muitos autores preferem as áreas da secção transversal do braço como método de avaliação nutricional, argumentando que estimam melhor a contribuição relativa da gordura e de músculo na ATB, comparativamente com os valores isolados do $\mathrm{PB}$ e da $\mathrm{PCT}^{(8)}$.

Utilizando métodos de referência - a tomografia axial computorizada e a ressonância magnética, ao utilizar a imagem do braço, as respetivas áreas da secção transversal estimadas por antropometria foram validadas tanto para crianças como para adultos ${ }^{(8)}$.

Área total do braço

É calculada a partir da expressão: $\mathrm{ATB}=\mathrm{PB}^{2} /(4 \mathrm{x} \pi)^{(19)}$ 


\section{Upper arm muscle area}

Upper arm muscle area is determined using the formula: $\mathrm{UAMA}=\left[\mathrm{MUAC}-(\mathrm{TST} \times \mathrm{x} \pi]^{2} /(4 \mathrm{x} \pi)^{(19)}\right.$

\section{Upper arm fat area}

Upper arm fat area is obtained by subtracting the UAMA from the UATA: UAFA = UATA - UAMA ${ }^{(19)}$

\section{Segments and diameters}

The measurements of segments and diameters analyse the dimensions of the underlying skeleton, since they are delimited by eminences or bone ends ${ }^{\left({ }^{8}\right)}$.

Considering that the growth of body segments is proportional to height, the measurement of certain segments such as foot length, knee-heel distance and elbow-wrist distance was proposed. These measurements allow detection of the minimum variations of daily growth, namely in preterm new-borns ${ }^{(8)}$.

For the measurement of segments and diameters, the measuring tape is the most accessible instrument, and it is possible to use stencils, calipers and compasses, which exert a firm pressure, minimising the effect of the soft tissues on the measurements, thus reducing the variability in certain circumstances ${ }^{(8)}$.

The use of diameters is based on the concept that the size of the skeleton is associated with fat-free mass ${ }^{(7)}$.

\section{Anthropometric indices}

All these somatic parameters, used alone and/or together, allow the calculation of indices that diagnose malnutrition, both in terms of form and degree ${ }^{(4)}$.

Anthropometric indices are combinations of measurements or relationships between measurements and other factors such as age, which are essential for their interpretation. For example, the value of body weight alone is meaningless unless it is related to the age or length/height of an individual ${ }^{(6)}$.

Height for age reflects linear growth, and deficits indicate cumulative health or nutrition deficits in the long term ${ }^{(3)}$. Weight for age reflects body mass in relation to age, but does not evaluate linear growth nor differentiate the nature of the nutritional deficit, that is, whether it is recent or long-standing ${ }^{(3)}$. It is a classification that does not consider stature, and therefore does not rigorously characterise the different forms of malnutrition (4). Weight for height reflects body weight in relation to

\section{Área muscular do braço}

Determinada recorrendo à fórmula: $\mathrm{AMB}=[\mathrm{PB}-$ $(\mathrm{PCT} \times \pi)]^{2} /(4 \mathrm{x} \pi)^{(19)}$

Área gorda do braço

Obtida através da subtração da AMB à ATB: AGB = $\mathrm{ATB}-\mathrm{AMB}^{(19)}$

\section{Segmentos e diâmetros}

As medições de segmentos e diâmetros analisam as dimensões do esqueleto subjacente, pois são delimitados por eminências ou extremidades ósseas ${ }^{(8)}$.

Considerando que o crescimento dos segmentos corporais é proporcional ao da estatura, foi proposta a medição de certos segmentos como o comprimento do pé, a distância joelho-calcanhar e cotovelo-punho. Estas medições permitem detectar as variações mínimas do crescimento diário, nomeadamente em recém-nascidos pré-termo ${ }^{(8)}$.

Para a medição de segmentos e diâmetros, a fita métrica é o instrumento mais acessível, podendo ser utilizado as craveiras, paquímetros e compassos, que exerçam uma pressão firme, permitindo minimizar o efeito dos tecidos moles nas medições, diminuindo desta forma a variabilidade em determinadas circunstâncias ${ }^{(8)}$.

O uso dos diâmetros baseia-se no conceito de que o tamanho do esqueleto está associado à massa isenta de gordura $^{(7)}$.

\section{Índices antropométricos}

Todos estes parâmetros somáticos, usados isoladamente e/ou em conjunto, permitem calcular índices que diagnosticam a malnutrição, quer quanto à forma quer quanto ao grau ${ }^{(4)}$.

Os índices antropométricos são combinações de medições ou relações entre medições e outros factores como a idade, essenciais para a sua interpretação. Por exemplo, o valor do peso corporal isoladamente não tem significado a não ser que seja relacionado com a idade ou com o comprimento/estatura de um indivíduo ${ }^{(6)}$.

A estatura para a idade, reflete o crescimento linear e os défices indicam deficiências cumulativas de saúde ou nutrição a longo prazo $^{(3)}$. O peso para a idade, reflete a massa corporal em relação à idade, mas não avalia o crescimento linear nem diferencia a natureza do défice nutricional, isto é, se é recente ou de longa data ${ }^{(3)}$. É uma classificação que não considera a estatura, e por isso, não caracteriza com rigor as diferentes formas de 
height. It has the advantage of not requiring knowledge of the age of the child ${ }^{(3)}$.

The body mass index (BMI) for age, expressed as a ratio of weight in kilograms $(\mathrm{kg})$ to height in square meters $\left(\mathrm{m}^{2}\right)$, should take into account the child's age and is a good nutritional indicator at population, and is particularly used in the diagnosis and follow-up of overweight and obese children ${ }^{(4)}$. The use of BMI charts for age is recommended to assess weight in relation to height of children and adolescents from 2 to 20 years of age ${ }^{(11)}$.

BMI is a good indicator of paediatric obesity and is independently correlated with health risk in children and adolescents. Nonetheless, BMI reflects both fat mass and fat-free mass and is not a direct measure of adiposity ${ }^{(7)}$. Several studies have shown a good correlation between BMI and body fat in groups, but the variation is large and BMI cannot accurately determine body fat in individuals ${ }^{(7)}$.

While there are still other indexes, BMI is the preferred method to assess the body weight of children, adolescents and adults ${ }^{(9)}$. BMI has a relatively high correlation with estimates of body fat and a low correlation with stature. It correlates well with estimates of body composition from three methods - body density, total body water and total body potassium - and is a convenient and reliable indicator of obesity ${ }^{(20)}$.

Several measurements and anthropometric indices have been associated with cardiovascular diseases, however, the superiority of the waist-to-height ratio has been demonstrated in relation to $\mathrm{WC}$ and BMI to identify cardiometabolic risk factors ${ }^{(21)}$.

The anthropometric indexes can be expressed as a Zscore, percentile, or percentage of the median, to compare a child or a group of children with a reference population ${ }^{(6)}$.

The Z-score expresses the anthropometric value as the number of standard deviations (SD) or Z-scores below or above the mean value of the reference ${ }^{(21)}$. Although $\mathrm{Z}$-score is recognised as the most appropriate for describing malnutrition, health and nutritional programs, in practice it has not always been adopted for individual assessment ${ }^{(21)}$.

The percentile refers to the position of an individual in a given reference distribution, establishing to what percentage of the group the individual equals, exceeds, or does not reach. Thus, a child of a certain age, whose weight is in the 10th percentile, weighs the same or more than $10 \%$ of the reference population of children of the same age ${ }^{(6)}$.

The percentage of the median refers to the percentage of the median of the predicted reference, i.e. the ratio malnutrição $0^{(4)}$. O peso para a estatura, reflete o peso corporal em relação à estatura. Tem a vantagem de não ser necessário conhecer a idade da criança ${ }^{(3)}$.

O índice de massa corporal (IMC) para a idade, expresso como uma razão entre o peso em quilogramas $(\mathrm{kg})$ e a estatura em metros quadrados $\left(\mathrm{m}^{2}\right)$, deve ter em consideração a idade da criança e é um bom indicador nutricional a nível populacional, sendo particularmente utilizado no diagnóstico e seguimento de crianças com excesso de peso e obesidade ${ }^{(4)}$. A utilização dos gráficos do IMC para a idade é recomendada para avaliar o peso em relação à estatura de crianças e adolescentes dos 2 aos 20 anos de idade ${ }^{(11)}$.

O IMC é um bom indicador de obesidade pediátrica e está independentemente correlacionado com o risco de saúde em crianças e adolescentes. Apesar de tudo, o IMC reflete tanto a massa gorda como a massa isenta de gordura e não é uma medida direta de adiposidade ${ }^{(7)}$ Diversos estudos mostraram uma boa correlação entre o IMC e a gordura corporal em grupos, mas a variação é grande e o IMC não pode com acurácia determinar a gordura corporal em indivíduos ${ }^{(7)}$.

Existem ainda outros índices, contudo o IMC é o preferível para avaliar o peso corporal de crianças, adolescentes e adultos ${ }^{(9)}$. O IMC tem uma correlação relativamente alta com estimativas da gordura corporal e uma correlação baixa com a estatura. Correlaciona-se bem com as estimativas da composição corporal provenientes de três métodos - densidade corporal, total de água corporal e total de potássio corporal, sendo um indicador de obesidade conveniente e confiável ${ }^{(20)}$.

Várias medidas e índices antropométricos têm sido associados à doença cardiovascular, contudo tem sido demonstrada a superioridade da razão perímetro da cintura/estatura relativamente ao PC e ao IMC para identificar fatores de risco cardiometabólicos ${ }^{(21)}$.

Os índices antropométricos podem ser expressos em: $Z$ -score, percentil ou percentual da mediana, que podem ser usados para comparar uma criança ou um grupo de crianças com uma população de referência ${ }^{(6)}$.

$\mathrm{O} Z$-score expressa o valor antropométrico como o número de desvios-padrão (DP) ou Z-scores abaixo ou acima do valor médio da referência ${ }^{(21)}$. Embora o Z-score seja reconhecido como o mais apropriado para a descrição da malnutrição, da saúde e de programas nutricionais, na prática nem sempre tem sido o adoptado para a avaliação individual ${ }^{(22)}$

$\mathrm{O}$ percentil refere-se à posição de um indivíduo numa determinada distribuição de referência, estabelecendo a que percentagem do grupo o indivíduo iguala, excede ou não alcança. Deste modo, uma criança de uma determinada idade, cujo peso se situe no percentil 10, pesa o 
of the measured value (such as the weight) of an individual and median value of the reference data for the same age or expressed length / height in percentage ${ }^{(6)}$.

Of the three systems used to express anthropometry, the WHO recommends the use of the Z-score system, as it has several qualities that make it superior to the other two systems ${ }^{(6)}$.

\section{The Nutritional assessment}

Nutritional assessment is essential for the recognition and diagnosis of nutritional status ${ }^{(3)}$. It is extremely important to determine the nutritional status of the population, as it is one of the best health indicators, individual and community, especially in children and adolescents, since their growth and development are largely conditioned by food and nutrition. Inadequate nutrition leads to malnutrition, either by default (undernutrition), or by excess (overnutrition) or by a specific lack or nutritional imbalance. It not only allows the diagnosis of malnutrition but also the identification of a child at nutritional risk, regardless of its form ${ }^{(2)}$.

The objective of this assessment of nutritional status is to assess body growth at different ages. Growth involves not only changes in anthropometric parameters, but also changes in body composition, namely fat mass and fatfree mass. These changes, characteristic of growth, occur in a continuous but non-uniform way, which makes it imperative to systematically evaluate the nutritional status of children, whether sick or healthy ${ }^{(4,5)}$.

Nutritional assessment includes four different components: anthropometric, biochemical, clinical and dietary ${ }^{(9,12)}$. In this work, the importance of anthropometry was characterised.

\section{The growth assessment}

The effect of nutrition on human growth and development has made the measurement of body weight and body dimensions necessary for the practice of nutritional assessment and growth ${ }^{(9)}$.

The assessment of growth is an important tool to deter- mesmo ou mais que $10 \%$ da população de referência de crianças da mesma idade ${ }^{(6)}$.

A percentual da mediana, refere-se à percentagem da mediana da referência prevista, isto é, a razão do valor medido de um indivíduo como por exemplo o peso e o valor da mediana dos dados de referência para a mesma idade ou comprimento/estatura expressa em percentagem $^{(6)}$.

Dos 3 sistemas utilizados para expressar a antropometria, a OMS recomenda o uso do sistema de Z-score, pois tem diversas qualidades que o tornam superior aos outros dois sistemas ${ }^{(6)}$.

\section{A avaliação nutricional}

A avaliação nutricional é essencial para o reconhecimento e diagnóstico da situação nutricional ${ }^{(3)}$. É de extrema importância determinar o estado nutricional das populações, pois é um dos melhores indicadores de saúde, individual e comunitária, muito particularmente na criança e no adolescente, já que o seu crescimento e desenvolvimento estão em grande parte condicionados pela alimentação e nutrição. Uma nutrição inadequada, conduz a um estado de malnutrição, quer por defeito (subnutrição), quer por excesso (supernutrição) ou ainda, a uma carência específica ou a um desequilíbrio nutricional. Permite não só diagnosticar a malnutrição mas também identificar a criança em risco nutricional, qualquer que seja a sua forma ${ }^{(2)}$.

A avaliação do estado nutricional, tem por objectivo, apreciar o crescimento corporal nas diferentes idades. O crescimento envolve não só alterações nos parâmetros antropométricos, mas também modificações na composição corporal, nomeadamente na massa gorda e na massa isenta de gordura. Estas alterações, características do crescimento, ocorrem de uma forma contínua mas não uniforme, o que torna premente a avaliação sistemática do estado nutricional de crianças quer estejam doentes ou saudáveis ${ }^{(4,5)}$.

A avaliação nutricional inclui quatro diferentes componentes: antropométrica, bioquímica, clínica e alimen$\operatorname{tar}^{(9,12)}$. Neste trabalho foi caracterizada a importância da antropometria.

\section{A avaliação do crescimento}

O efeito da nutrição no crescimento e desenvolvimento humano tornou a medição do peso e das dimensões corporais, indispensáveis para a prática da avaliação nutricional e do crescimento $^{(9)}$.

A avaliação do crescimento é um instrumento impor- 
mine health, both individually and collectively ${ }^{(23)}$. It is the measurement that best defines the health and nutritional status of children, because disorders in health and nutrition, taking into account their etiology, invariably affect child growth ${ }^{(24)}$. Thus, the evaluation of growth allows us to know the health and nutritional status of the child, which in turn is an indirect measure of the socioeconomic status and the quality of life of a population ${ }^{(22,24)}$.

Several situations frequently lead to deficits in growth, so their identification is an important means of early detection of problems ${ }^{(25)}$.

When evaluating growth, it is important to keep in mind several factors: it is fundamental to trace the evolution curve of weight and length/height; the sudden changes in this curve are more important and significant than the absolute values of weight and length/height; the changes are less significant between the 25th and 75th percentiles; children below the 5th percentile or above the 95th percentile require more vigilance; the weightheight relationship may be particularly significant for assessing the nutritional status ${ }^{(26)}$.

Even in cases that are below the 5th percentile or above the 95th percentile, all data regarding family history, weight evolution curve, and others must be taken into account. If a child has been below the 5 th percentile since birth, this does not have the same meaning as a rapid percentile change ${ }^{(26)}$.

In assessing the growth or nutritional status of children, tables that relate weight and length/height to age may be particularly informative. Low-length/height-for-age situations, but with normal weight, may be a reflection of nutritional problems or growth retardation in the past. If both (weight and length/height) are low for age, then we may be faced with a nutritional problem or growth delay not only in the past, but also in the present. On the contrary, if a child has normal length/height for age but abnormally low weight for length/height, we may be facing an acute problem.

In this way, growth charts can help distinguish a normal from an abnormal pattern.

To assess growth velocity, growth charts are also assessment useful tool and indicate how quickly the child is growing over a period of time, and may show a significant signal of deceleration or acceleration of these patterns ${ }^{(11)}$.

In short, anthropometric evaluation is essential to recognise growth deviations and should be a standardised clinical practice ${ }^{(27)}$. tante para se conhecer a saúde, individualmente e colectivamente $^{(23)}$. É a medição que melhor define o estado de saúde e nutricional de crianças, porque distúrbios na saúde e nutrição, tendo em consideração a sua etiologia, afectam invariavelmente o crescimento infantil ${ }^{(24)}$. Assim, a avaliação do crescimento permite conhecer o estado de saúde e nutricional da criança, que por sua vez, é uma medida indireta do estatuto socioeconómico e da qualidade de vida de uma população ${ }^{(22,24)}$.

Várias situações provocam frequentemente défices no crescimento pelo que a sua identificação é um meio importante para detectar problemas precocemente ${ }^{(25)}$.

$\mathrm{Na}$ avaliação do crescimento é importante ter sempre presente que: é fundamental traçar a curva de evolução do peso e comprimento/estatura; são mais importantes e significativas as mudanças bruscas dessa curva que os valores absolutos de peso e comprimento/estatura; as mudanças são menos significativas entre os percentis 25 e 75; as crianças abaixo do percentil 5 ou acima do percentil 95 requerem maior vigilância; a relação peso/ estatura pode ser particularmente significativa para avaliar o estado de nutrição ${ }^{(26)}$.

Mesmo nos casos que se situam abaixo do percentil 5 ou acima do percentil 95 , há que ter em conta todos os dados referentes à história familiar, curva de evolução ponderal, entre outros. Se uma criança esteve abaixo do percentil 5 desde o nascimento, tal facto não tem o mesmo significado do que uma mudança rápida de percentil ${ }^{(26)}$.

$\mathrm{Na}$ avaliação do crescimento ou do estado nutricional das crianças, as tabelas que relacionam o peso e comprimento/estatura para a idade podem ser particularmente informativas. Situações de baixo comprimento/estatura para a idade, mas peso normal, podem ser reflexo de problemas nutricionais ou de atraso de crescimento no passado. Se ambos (peso e comprimento/estatura) são baixos para a idade, podemos então estar perante um problema nutricional ou atraso de crescimento não só passado, como atual. Pelo contrário, se uma criança tem comprimento/estatura normal para a idade, mas peso anormalmente baixo para o comprimento/estatura, podemos estar perante um problema agudo.

Desta forma, os gráficos de crescimento, podem ajudar a distinguir um padrão normal de um anormal.

Para avaliar a velocidade de crescimento, os gráficos de crescimento são também um instrumento de avaliação e indicam com que rapidez a criança está a crescer durante um período de tempo, podendo mostrar um sinal significativo de desaceleramento ou aceleramento desses padrões ${ }^{(11)}$.

Em suma, a avaliação antropométrica, é essencial para reconhecer os desvios do crescimento, devendo constituir uma prática clínica padronizada ${ }^{(27)}$. 


\section{Anthropometric references}

For a correct interpretation of the measurements, it is imperative to compare the results with reference values representative of the population to which the individual belongs. In its absence, common in many circumstances, comparisons are made with reference values of other populations, but it must be taken into account that they may not be perfectly extrapolated to the individual being evaluated ${ }^{(8)}$.

In growth assessment, it is common to use growth curves as if they were patterns. This is in error, because the whole pattern is a reference, but not all the reference is standard. A standard is something that everyone has to match, a reference to make comparisons. Thus, any curve used, whether for nutritional diagnosis of populations or to evaluate individual growth, should not be standardized ${ }^{(23)}$.

A reference is defined as an instrument for grouping and evaluating data, which provides a common basis for comparing populations. A standard, on the contrary, encompasses the notion of a desirable model and goal and therefore implies a value judgment ${ }^{(6)}$. Thus, assessment of nutritional status and growth are performed by comparison with reference values ${ }^{(23)}$.

In the updating of the reference data, it is important to consider that human variables change over time (secular changes) and that they vary within different groups and geographical areas (racial and geographical variations) ${ }^{(28)}$.

The references may be local or international, and each have advantages and limitations which have been discussed over the years, raising the question of the need for growth references developed by each country or whether a single international reference would be sufficient ${ }^{(29)}$.

We believe that both are important. The international reference is useful for establishing comparisons between populations, creating a uniformity of criteria. The local references more accurately reflect the study population, allowing a nutritional screening that can serve as a basis for nutritional programs.

When used in clinical practice, curves explain adequate and inadequate growth patterns, and identify situations of growth changes re-evaluated over time. They are useful because they help determine to what extent the physiological needs that ensure growth and development are being met during the important periods of childhood and adolescence ${ }^{(30)}$.

\section{Referências antropométricas}

Para uma correta interpretação das medidas efectuadas, é imperioso comparar os resultados com valores de referência representativos da população a que pertence o indivíduo. Na sua ausência, comum em muitas circunstâncias, compara-se com valores de referência de outras populações, mas é necessário ter em consideração que os mesmos poderão não ser perfeitamente extrapoláveis para o indivíduo sob avaliação ${ }^{(8)}$.

$\mathrm{Na}$ avaliação do crescimento, é comum usar as curvas de crescimento como se fossem padrões. Erro, pois todo o padrão é uma referência, mas nem toda a referência é padrão. Padrão é algo a que todos têm que se igualar, referência serve para se fazer comparações. Assim, qualquer curva que se utilize, seja para fazer o diagnóstico nutricional de populações ou para avaliar o crescimento individual, não o deve ser como padrão ${ }^{(23)}$. Define-se referência como um instrumento para agrupar e avaliar dados, que proporcionou uma base comum para comparar populações. Um padrão, pelo contrário abarca a noção de modelo e meta desejável e por isso implica um juízo de valor ${ }^{(6)}$. Assim, a avaliação do estado nutricional e do crescimento são efectuadas por comparação com valores de referência ${ }^{(23)}$.

$\mathrm{Na}$ elaboração dos dados de referência é importante considerar que as variáveis humanas sofrem alterações com o tempo (alterações seculares) e que variam dentro de diferentes grupos e áreas geográficas (variação racial e geográfica) ${ }^{(28)}$.

As referências podem ser locais ou internacionais, tendo cada uma vantagens e limitações, que têm sido discutidas ao longo dos anos, levantando-se a questão da existência de referências de crescimento, desenvolvidas por cada país ou se uma única referência internacional seria suficiente ${ }^{(29)}$.

Consideramos que ambas são importantes. A referência internacional é útil para estabelecer comparações entre populações, criando uma uniformização de critérios. As referências locais refletem com maior exatidão a população estudada, permitindo um rastreio nutricional que pode servir de base para programas nutricionais.

Quando usadas na prática clínica, as curvas explicam os padrões de crescimento adequados e inadequados, e identificam situações de alterações de crescimento reavaliadas ao longo do tempo. São úteis porque ajudam a determinar até que ponto estão a ser satisfeitas as necessidades fisiológicas que assegurem o crescimento e o desenvolvimento durante o importante período da infância e adolescência ${ }^{(30)}$. 


\section{Conclusions}

Nutritional and growth assessment implies a correct use and interpretation of anthropometric variables. The main measures and anthropometric indexes for children and adolescents were described in this text. Accuracy in measurement was emphasized, as well as the appropriate comparisons with the most suitable references for their purpose, thus allowing a correct assessment of the situation.

\section{Conflict of interests}

The author declares that there is no personal or financial relationship that can be understood as presenting a potential conflict of interest.

\section{Conclusões}

A avaliação nutricional e do crescimento implica uma correta utilização e interpretação das variáveis antropométricas. Foram aqui descritas as principais medidas e índices antropométricos para crianças e adolescentes, e realçado o rigor na medição assim como a adequada comparação com as referências mais adequadas para o fim a que se destinam e assim permitir um correto diagnóstico da situação.

\section{Conflito de interesses}

O autor declara não existir qualquer relação pessoal ou financeira que possa ser entendida como representando um potencial conflito de interesses. 


\section{References / Referências}

(1) Fidanza F. Anthropometry Methodology. In: Nutrition Status Assessment. London: Chapman \& Hall;1991.p.1-44.

(2) Guerra AJM, Teixeira Santos N, Almeida Santos L, Carreiro E, Morais MR, Prata A, et al. Avaliação Nutricional Infantil. Rev Port Pediatr 1990;21:5-46.

(3) Rito A, dos Anjos LA. Critérios Actuais na Antropometria Nutricional de Crianças. Alimentação Humana 2002;8(2):47-59.

(4) Guerra AJM. Avaliação Nutricional Infantil. In:Orientação Diagnóstica em Pediatria; Vol1. Lisboa:Lidel;2002.p.127-36.

(5) Guerra A. Avaliação do Estado de Nutrição. In: da Silva AC, Gomes-Pedro J editors. Nutrição Pediátrica - Princípios Básicos; Lisboa:Clínica Universitária de Pediatria - Hospital Santa Maria;2005.p.149-58.

(6) WHO: World Health Organization. Expert Committee. Physical status: the use and interpretation of anthropometry. Geneva: WHO;1995.

(7) Sopher A, Shen W, Pietrobelli. Pediatric Body Composition Methods. In:Heymsfield SB, Lohman TG, Wang Z, Going SB editors. Human Body Composition. 2nd edition. Champaign: Human Kinetics;2005:129-39.

(8) Pereira-da-Silva L, Virella D, Videira Amaral JM, Guerra A. Antropometria no Recém-nascido: Revisão e Perspectiva actual. Lisboa: Nestlé Nutrition Portugal;2007.

(9) Lee RD, Nieman DC. Nutritional Assessment. 4th ed. New York: McGraw-Hill Companies;2007.

(10) Teixeira Santos N. Avaliação Nutricional Infantil. In: Temas de Pediatria. Lisboa:Sandoz-Wander;1982(1):243-303.

(11) Nevin-Folino NL, editor. Pediatric Manual of Clinical Dietetics. 2nd ed. United States of America: American Dietetic Association;2003.

(12) Jelliffe DB, Jelliffe EPF. Community Nutritional Assessment. Oxford: Oxford University Press; 1989.

(13) Taylor RW, Jones IE, Williams SM, Goulding A. Evaluation of waist circumference, waist-to-hip ratio, and conicity index as screening tools for high trunk fat mass, as measured by dual-energy X-ray absorptiometry, in children aged 3-19 y. Am J Clin Nutr 2000;72:490-5.

(14) Maffeis C, Pietrobelli A, Grezzani A, Provera S, Tato L. Waist circumference and cardiovascular risk factors in prepubertal children. Obes Res 2001 Mar;9(3):179-87.

(15) McCarthy HD, Ellis SM, Cole TJ. Central overweight and obesity in British youth aged 11-16 years: cross sectional surveys of waist circumference. BMJ 2003 Mar 22;326(7390):624-7.

(16) Gibson RS. Principles of Nutritional Assessment. 2nd edition. Oxford: Oxford University Press;2005.

(17) WHO: World Health Organization. Expert Committee. Obesity: Preventing and Managing the Global Epidemic. Geneva: WHO;2000.

(18) Norton K, Whittingham N, Carter L, Kerr D, Gore C, Marfell-Jones M. Técnicas de Medição em Antropometria. In: Norton K, Olds T editors. Antropométrica. Porto Alegre; Artmed:2005:173-99.

(19) Frisancho AR. Anthropometric Standards -An Interactive Nutritional Reference of Body Size and Body Composition for children and Adults. The University of Michigan Press;2008.

(20) Garrow JS, Webster J. Quetelet's index (w/h2) as a measure of fatness. Int J Obes 1985;9(2):147-53.

(21) Yoo EG. Waist-to-height ratio as a screening tool for obesity and cardiometabolic risk. Korean J Pediatr 2016 Nov;59(11):425-31.

(22) WHO: World Health Organization. World Health Organization/Programme of Nutrition WHO Global Database on Child Growth and Malnutrition; Citado em 2004 Aug 2. Disponível em: www.who.int/nutgrowthdb/intro_text.htm.

(23) Zeferino AMB, Filho AAB, Bettiol H, Barbieri MA. Acompanhamento do crescimento. J Pediatr 2003; 79(supl.1):S23-S32.

(24) de Onis M, Monteiro C, Akré J, Clugston G. The world magnitude of protein-energy malnutrition: an overview from the WHO Global Database on Child Growth. Bull World Health Organ 1993;71(6):703-12.

(25) Shrimpton R, Victora CG, de Onis M, Lima RC, Blossner M, Clugston G. Worldwide timing of growth faltering: implications for nutritional interventions. Pediatrics 2001 May;107(5):E75.

(26) DGCSP: Direcção Geral dos Cuidados de Saúde Primários. Orientações Técnicas - Crescimento e maturação dos 0-18 anos. Lisboa: DGCSP;1989.

(27) de Onis M. The use of anthropometry in the prevention of childhood overweight and obesity. Int J Obes Relat Metab Disord 2004 Nov; 28 Suppl 3:S81-5.

(28) Kirk J. Growth and nutritional assessment of children. In: Holden C, MacDonald A, editors. Nutrition and Chid Health. London: Baillière Tindall;2000.p.161-76.

(29) Gibson RS. Anthropometric Reference Data. In: Principles of Nutritional Assessment. Oxford: Oxford University Press;1990.p.209-42.

(30) de Onis M, Victora CG. Growth charts for breastfed babies. J Pediatr (RioJ) 2004 Mar-Apr;80(2):85-7. 